\title{
Decision Tree Algorithm in Identifying Specific Interventions for Gender and Development Issues
}

\author{
Rolaida L. Sonza1,2, Gilbert M. Tumibay² \\ ${ }^{1}$ Nueva Ecija University of Science and Technology, Cabanatuan, Philippines \\ ${ }^{2}$ Angeles University Foundation, Graduate School, Angeles, Philippines \\ Email:rolaidasonza@yahoo.com,tumibay.gibo@auf.edu.ph
}

How to cite this paper: Sonza, R.L. and Tumibay, G.M. (2020) Decision Tree Algorithm in Identifying Specific Interventions for Gender and Development Issues. Journal of Computer and Communications, $\mathbf{8}$, 17-26.

https://doi.org/10.4236/jcc.2020.82002

Received: July 3, 2019

Accepted: February 11, 2020

Published: February 14, 2020

Copyright $\odot 2020$ by author(s) and Scientific Research Publishing Inc. This work is licensed under the Creative Commons Attribution International License (CC BY 4.0). http://creativecommons.org/licenses/by/4.0/

\begin{abstract}
The State Universities and Colleges (SUCs) in the Philippines have established a model of Gender and Development (GAD) tools. They have different activities but lack of organized data sources with particular data needed for gender analysis like the sex-disaggregated data. GAD data is very important in gender analysis to enable the GAD Focal Point System to have the basis for gender issues and concerns. In this paper, the authors present information technology-based solution where the GAD Focal Point System has basis for gender analysis and proposed undertakings using a classification system like decision tree algorithm. The approach is better for discovering relevant solutions in improving university programs and activities to achieve the goal of gender equality.
\end{abstract}

\section{Keywords}

Automation, Gender and Development, Information Technology, Solutions, Sex-Disaggregated Data

\section{Introduction}

Nowadays the ways in which things are done using technology are refined and welcoming. Everything turns to computerization, people are connected to internet, some are using robotics, dependent on IoT, making the transaction fast, proceeding to paperless operation and implementing different algorithms in data science like decision tree algorithm.

Currently, there is an increase of applications of decision tree algorithm in different aspects of life such as in business management, educational manage- 
ment, clinical decision support, engineering, and solutions with situation awareness. In terms of problems solution, the Gender and Development (GAD) in different government agencies have yearly plan and budget that requires them to implement projects, programs or activities to minimize the gap of women and men and eliminate discriminations. In GAD, each person has equal opportunities in achieving satisfying life that promotes gender equality through responsive projects that provide the needs of men and women particularly the marginalized such as indigenous people, women in especially difficult circumstances and all discriminated individuals. Due to the existing discrimination and gender biases in the Philippines, the highest authority mandates all the government agencies included the State Universities and Colleges (SUCs) and local government units to use at least five percent (5\%) of the total budget appropriations of agency to support the projects of GAD that address gender issues and concerns [1]. Millions of funds are allotted by the state universities in GAD projects and activities. But then, the Philippine Commission on Women, Commission on Higher Education and Commission on Audit of the government also take a look if the projects are properly aligned, really help the community, taking up gender equality perspectives and must be mainstreamed into different activities of the education institution.

Based on interviews from SUCs GAD Focal Persons in the First Luzon SUCs GAD Advocacy Forum last November 17, 2017, most of them have enrolment data as the basis of their gender issues but lack of significant data that can monitor the needs of clients, gender issues and problems of their students and employees and have hard time to think GAD projects or activities. Similarly, most of the SUCs do not maximize the use of their GAD budget and failed in the approval of PCW in their accomplishment report and GAD Plan and Budget (GPB).

More so, this paper presents a mechanism to automate the process of determining gender issues and its equivalent solutions through technology-based solutions. Where the time and effort consumed by the GAD Focal Point system in the university in identifying the issues and solutions will be lessened and have their concrete bases for that purpose and achieve gender equality and inclusivity.

\section{Research Elaboration}

The Philippine Plan for Gender and Development (PPGD) 1995-2025 was established to pursue the full operation of equality for men and women. This plan was approved and adopted by former President Fidel V. Ramos as Executive No. 273, on September 8, 1995. The institutionalization of Gender and Development in the government was stated in this plan in which then incorporated the GAD concerns on the planning, programming and budgeting processes, and annual performance reports [2].

The country continued to support the plan through the formation of various laws like the Magna Carta of Women which was approved on August 14, 2009. 
This mandate is non-discriminatory and pro-gender equality and equity in the formulation and implementation of policies and plans for national development [3].

The Commission on Higher Education (CHED) made their efforts to mainstream GAD. In the article of Manzanan in 2015 stated that CHED led various efforts to attain gender equality in the academe. It started in 2010 where CHED established the GAD Focal Point in regional offices. CHED organized education summits on gender issues from 2011 to 2014 . The commission also led the formulation of CHED memorandum 1. s. 2015 to help the academe in the implementation of GAD [4].

In the CMO 1, s. 2015, it was stated that Higher Education Institutions (HEIs) need to form a GAD database and report on the status of GAD implementation. It is the basis of the researcher to continue and pursue this research where the data for individuals are gathered, analyzed and presented by sex and age and reflect problems, issues and questions related to women and men in society [5]. More so, it is to help the implementers in identifying the possible solutions based on the GAD data.

The Los Baños of Laguna Philippine have their GAD database spearheaded by their GAD Office. They have a strong belief that it is essential in their planning, programming, and policy formulation. The purpose also of this technology-based system is to share their information with the interested researchers. Their database has a list of sectors such as social development, economic development, infrastructure, environment, institutional and gender mainstreaming. The GAD Office also promises to continuously and regularly monitor and update the database to make sure that all possible facets of necessary data are covered [6].

Cornwall (2000) claimed the importance of exploring the gender dimension on participation in project, planning and policy processes to attain participatory development and make the society in Africa and Asia more gender-sensitive and responsive [7]. Eveline and Bacchi took emphasis on the gender mainstreaming development where can incorporate the programs for women and men for the full implementation of it for gender equality [8]. The article of McNutt and Beland shows that there are many nations adopted the gender equality policy tools but the problem is that they do not institutionalize it. Mainstreaming gender equality is not enough and needs to improve. Canada reaches the gender-based analysis but lacking in the implementation of programs and projects for gender equality. The need to develop a truly transformative mainstreaming strategy is also needed. More effort needs to be made to work in a variety inclusive which disrupts the status quo, introduces new policy ideas, shifts policy-making practices, and more effectively moves towards social justice [9].

Song and $\mathrm{Lu}$ (2015) stated that decision tree is usually used for establishing classification systems based on multiple covariates. This method classifies data into branch-like structure that builds an inverted tree with a root node, internal 
nodes, and leaf nodes. The algorithm can efficiently deal with complicated datasets, large and complicated parametric structures [10]. Kaur and Chhabra (2014) used classification algorithms for the prediction of diabetes. The Pima Indians Diabetes Data Set is used in their paper which collects the information of persons with and without having diabetes. The modified J48 classifier is used to increase the accuracy rate of the data mining procedure. The data mining tool WEKA has been used as an API of MATLAB for generating the J-48 classifiers. Experimental results showed a significant improvement over the existing J-48 algorithm. The steps they performed for data mining in WEKA are data pre-processing and visualization, attribute selection, classification using Decision trees, prediction using the nearest neighbor, model evaluation [11].

According to Phyu, decision trees tend to perform better when dealing with discrete/categorical features [12]. One of the most useful characteristics of decision trees is their comprehensibility. People can easily understand why a decision tree classifies an instance as belonging to a specific class. Since a decision tree constitutes a hierarchy of tests, an unknown feature value during classification is usually dealt with bypassing the example down all branches of the node where the unknown feature value was detected, and each branch outputs a class distribution. The output is a combination of the different class distributions that sum to 1. Baik (2004) utilized the decision tree in the distributed data for intrusion detection. In the approach, the method integrates inductive generalization and agent-based computing, so that classification rules are learned via tree induction from distributed data to be used as intrusion profiles. It shows that the decision tree is better in this method [13].

Automation is the technology by which a process or procedure is performed with minimal human assistance [14] [15]. This is one of the objectives of the study, to help the GFPS in thinking the right solutions to the issues identified in a short period of time.

\section{Results and Discussion}

The researchers used the developmental method in improving and integrating features of automating the process of recommending the GAD solutions to the digital applications for State Universities in the Philippines. In improving the system, the agile process model that adopts iterative development was utilized [16] [17]. The combination of coding, verification, unit testing and debugging for necessary working meaningful applications are done in making an effective system.

\subsection{Data Collections}

The dynamic data sources were utilized as sources of information. Without this software, there is a limited option to identify gender issues in the university. Among the data sources used by the researchers are coming from the researchers' developed applications. The data are collected from Nueva Ecija University 
of Science and Technology-Philippines.

\subsection{Logical Implementation of Automation Using Decision Tree Algorithm}

As shown in Figure 1 is the Decision Tree Algorithm used in automating the recommendation for GAD solutions. The tree can be explained by two entities, namely decision nodes and leaves. The leaves are the decisions or final outcomes. The system gathered different data and determined if the sex-disaggregated data or the data with GAD problems have gender issues or no gender issues. From the data where there are identified GAD issues are the bases of the GAD solutions. Wherein one data can identify GAD issues and from GAD issues can have different GAD solutions and classified as projects, programs or strategies.

\subsection{GAD Solutions Reports}

The different applications are innovated by adding features that automatically recommends solutions based on GAD problems identified within the databases. The recommendations are validated from the Philippine Commission on Women Resource Pool and members of GAD Focal Point System of different State Universities in the Philippines. Some of the reports obtained are shown in Figure 2, Figure 3, Figure 4, Table 1 and Table 2.

Figure 3 shows the GAD data with 43 Likes and 0 Dislike. The system provides 1 strategy which is to provide more media related to the article.

The solutions identified from data are so much plenty which is more than 10 times as compared to the previous GAD plan and budget. Within the system, just an instant, if data are available, automatically provide the right solutions. The solutions identified are recommended by the GAD Focal persons of different universities in Region III.

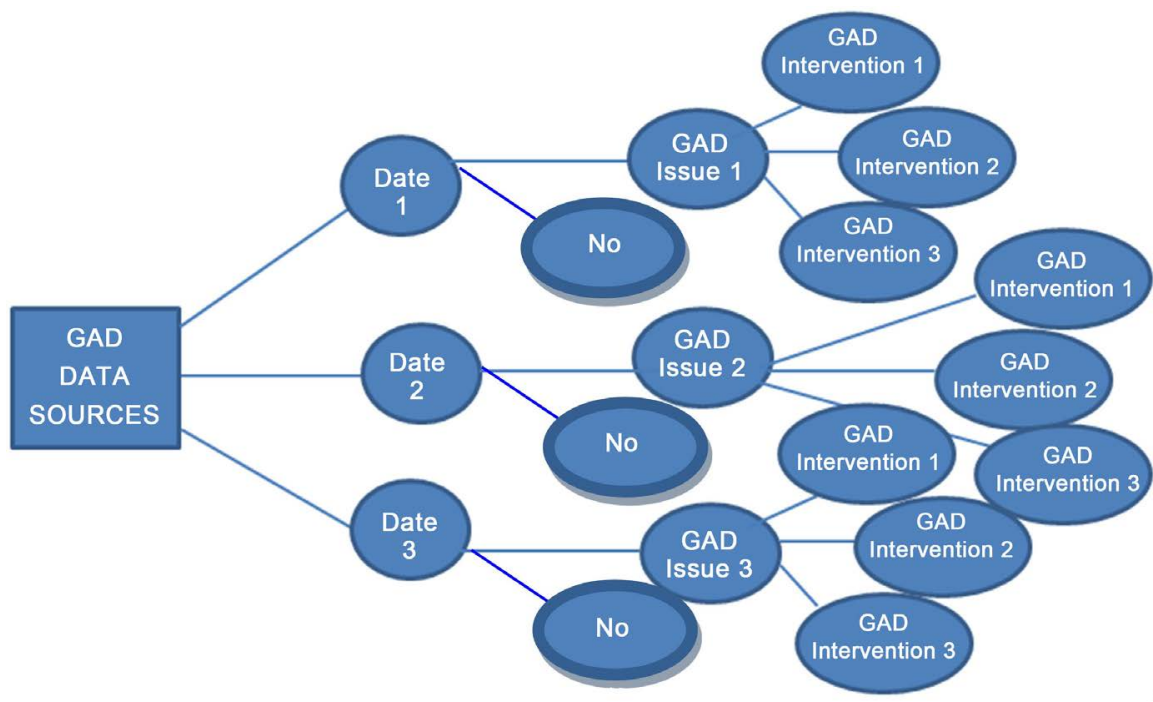

Figure 1. Logical implementation of decision tree in automating the recommendations for GAD solutions. 


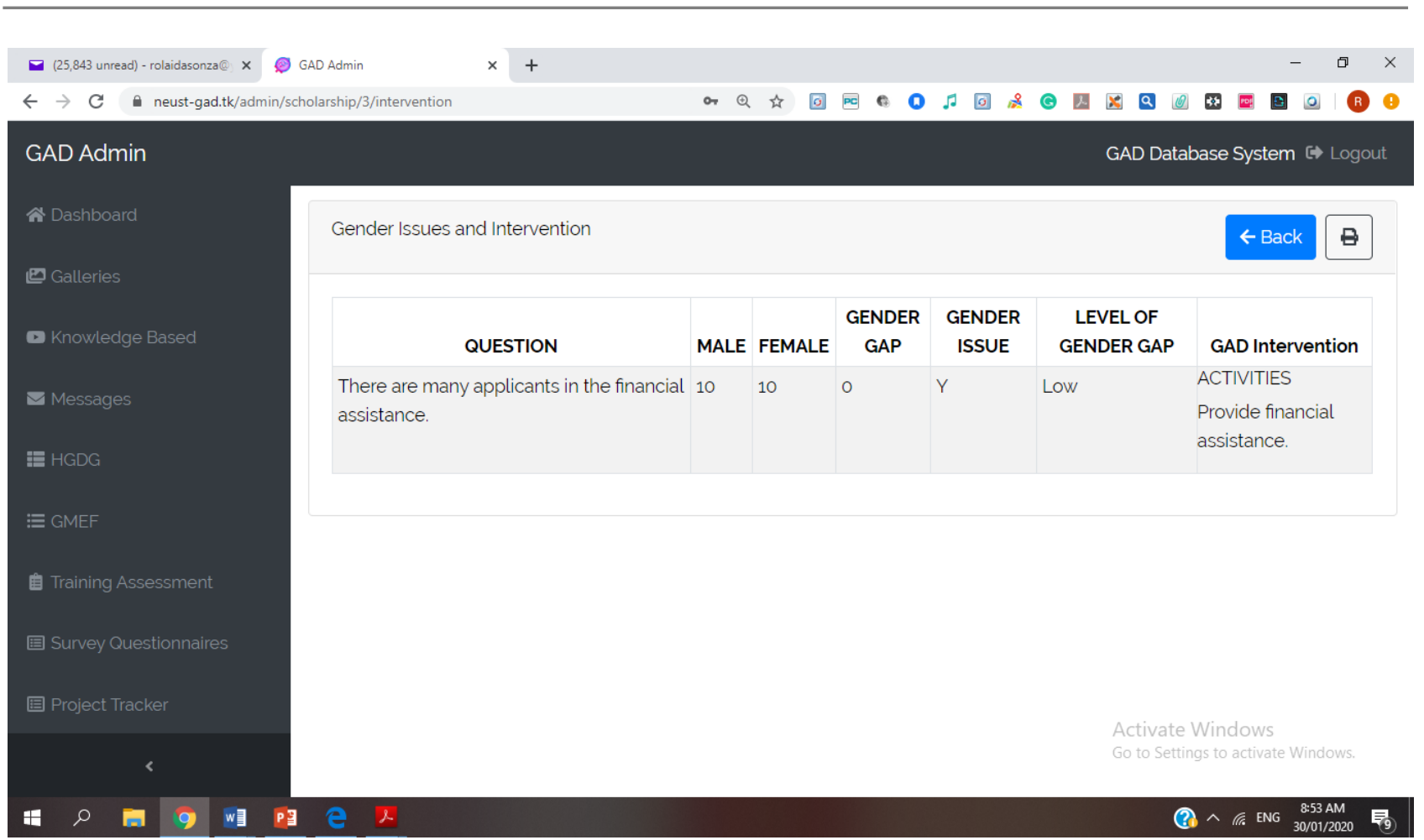

Figure 2. GAD solutions to the applicants for orphan financial assistance.

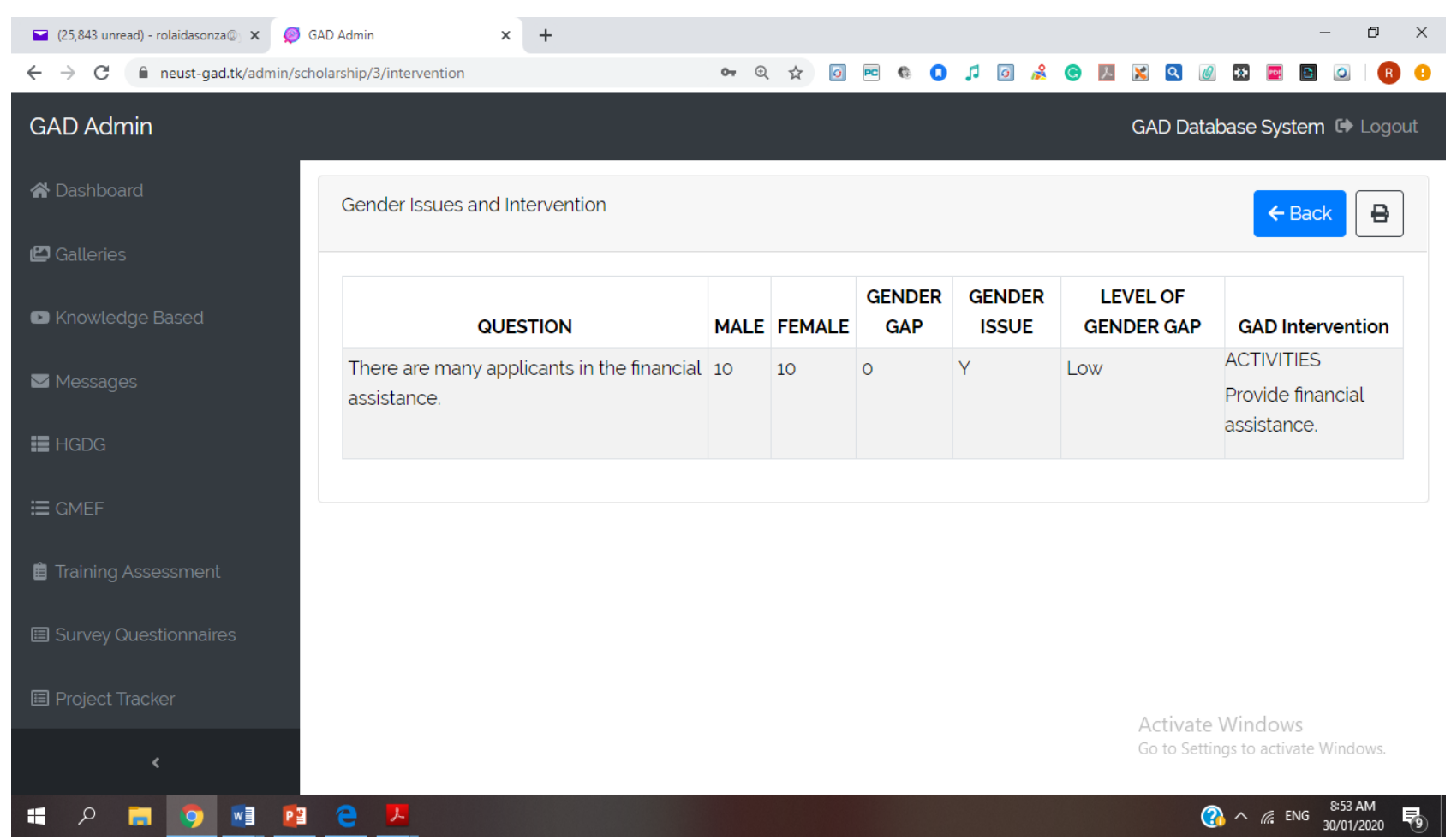

Figure 3. GAD intervention for knowledge-based system.

The data collected were verified the accuracy using the Machine Learning Tool called Waikato Environment Knowledge Analysis (WEKA) version 3.8 of Experimenter App. Not all data are verified. The data such as training needs 
Table 1. Gender issues and GAD intervention from survey system (profile).

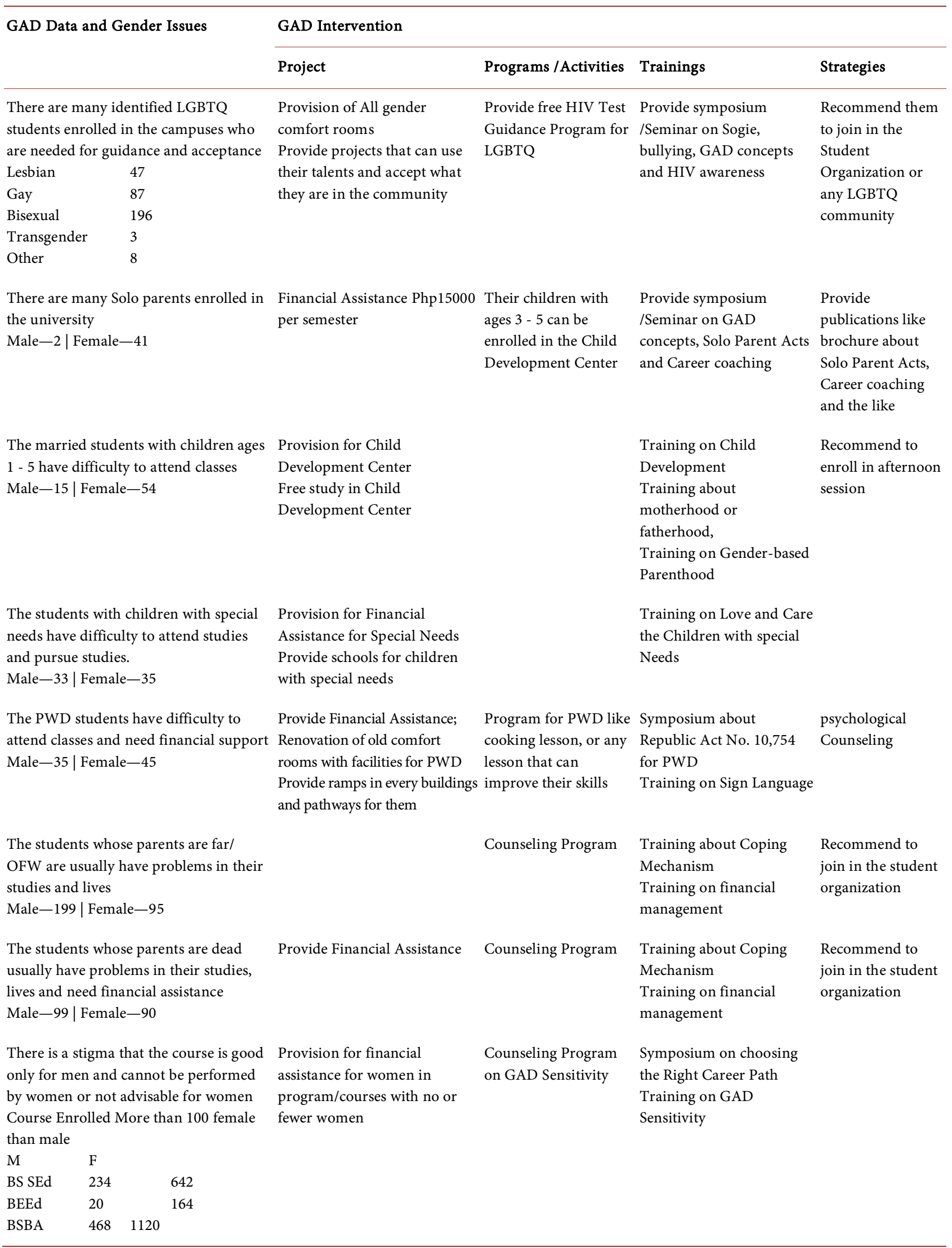


Table 2. Gender issues and GAD intervention from survey system (training assessment).

\begin{tabular}{|c|c|c|c|c|}
\hline \multirow[t]{2}{*}{ GAD Data and Gender Issues } & \multicolumn{4}{|l|}{ GAD Intervention } \\
\hline & Project & $\begin{array}{l}\text { Programs } \\
\text { /Activities }\end{array}$ & Trainings & Strategies \\
\hline $\begin{array}{l}\text { Limited knowledge to differentiate Sex and Gender } \\
\text { Many students are Not Aware to differentiate Sex } \\
\text { and Gender } \\
\text { Male-571| Female-225 }\end{array}$ & $\begin{array}{l}\text { Provide GAD corner } \\
\text { Update the GAD corner } \\
\text { information }\end{array}$ & & $\begin{array}{l}\text { Conduct Gender } \\
\text { Sensitivity } \\
\text { Training }\end{array}$ & $\begin{array}{l}\text { Make and distribute } \\
\text { leaflets about Sex and } \\
\text { Gender }\end{array}$ \\
\hline $\begin{array}{l}\text { Limited knowledge on Gender and Development } \\
\text { Many students are Not Aware on Gender and } \\
\text { Development } \\
\text { Male-521| Female-221 }\end{array}$ & $\begin{array}{l}\text { Provide GAD corner } \\
\text { Update the GAD corner } \\
\text { information }\end{array}$ & $\begin{array}{l}\text { Integrate GAD in } \\
\text { various courses and } \\
\text { school activities }\end{array}$ & $\begin{array}{l}\text { Conduct Gender } \\
\text { Sensitivity } \\
\text { Training }\end{array}$ & $\begin{array}{l}\text { Make and distribute } \\
\text { leaflets about Gender and } \\
\text { Development }\end{array}$ \\
\hline $\begin{array}{l}\text { Limited knowledge on Gender Analysis } \\
\text { Many students are Not Aware on Gender Analysis } \\
\text { Male-726 | Female-492 }\end{array}$ & $\begin{array}{l}\text { Provide GAD corner } \\
\text { Update the GAD corner } \\
\text { information }\end{array}$ & $\begin{array}{l}\text { Integrate GAD in } \\
\text { various courses and } \\
\text { school activities }\end{array}$ & $\begin{array}{l}\text { Conduct Gender } \\
\text { Analysis } \\
\text { Training }\end{array}$ & $\begin{array}{l}\text { Make and distribute } \\
\text { leaflets Gender Analysis } \\
\text { about }\end{array}$ \\
\hline $\begin{array}{l}\text { Limited knowledge on Gender Mainstreaming } \\
\text { Many students are Not Aware on Gender } \\
\text { Mainstreaming } \\
\text { Male-1186 | Female-1048 }\end{array}$ & $\begin{array}{l}\text { Provide GAD corner } \\
\text { Update the GAD corner } \\
\text { information }\end{array}$ & $\begin{array}{l}\text { Integrate } \mathrm{GAD} \text { in } \\
\text { various courses and } \\
\text { school activities }\end{array}$ & $\begin{array}{l}\text { Conduct Gender } \\
\text { Sensitivity } \\
\text { Training }\end{array}$ & $\begin{array}{l}\text { Make and distribute } \\
\text { leaflets about Gender } \\
\text { Mainstreaming }\end{array}$ \\
\hline $\begin{array}{l}\text { Limited knowledge on Gender-Fair Language } \\
\text { Male-1251 | Female-1121 }\end{array}$ & $\begin{array}{l}\text { Provide GAD corner } \\
\text { Update the GAD corner } \\
\text { information }\end{array}$ & $\begin{array}{l}\text { Integrate GAD in } \\
\text { various courses and } \\
\text { school activities }\end{array}$ & $\begin{array}{l}\text { Conduct Gender } \\
\text { Fair Language } \\
\text { Symposium }\end{array}$ & $\begin{array}{l}\text { Make and distribute } \\
\text { leaflets about Gender-Fair } \\
\text { Language }\end{array}$ \\
\hline $\begin{array}{l}\text { Limited knowledge on UN-CEDAW } \\
\text { Many students are Not Aware on UN-CEDAW } \\
\text { Male-1818 | Female-1845 }\end{array}$ & $\begin{array}{l}\text { Provide GAD corner } \\
\text { Update the GAD corner } \\
\text { information }\end{array}$ & $\begin{array}{l}\text { Integrate GAD in } \\
\text { various courses and } \\
\text { school activities }\end{array}$ & $\begin{array}{l}\text { Conduct } \\
\text { UN-CEDAW } \\
\text { Symposium }\end{array}$ & $\begin{array}{l}\text { Make and distribute } \\
\text { leaflets about Convention } \\
\text { on the Elimination of All } \\
\text { Forms of Discrimination } \\
\text { Against Women }\end{array}$ \\
\hline $\begin{array}{l}\text { Limited knowledge on Anti-Sexual Harassment Law } \\
\text { (RA 7877) } \\
\text { Male-1571 | Female-1513 }\end{array}$ & $\begin{array}{l}\text { Provide GAD corner } \\
\text { Update the GAD corner } \\
\text { information }\end{array}$ & $\begin{array}{l}\text { Integrate GAD in } \\
\text { various courses and } \\
\text { school activities }\end{array}$ & $\begin{array}{l}\text { Conduct } \\
\text { UN-CEDAW } \\
\text { Symposium }\end{array}$ & $\begin{array}{l}\text { Make and distribute } \\
\text { leaflets about on } \\
\text { Anti-Sexual Harassment } \\
\text { Law (RA 7877) }\end{array}$ \\
\hline
\end{tabular}

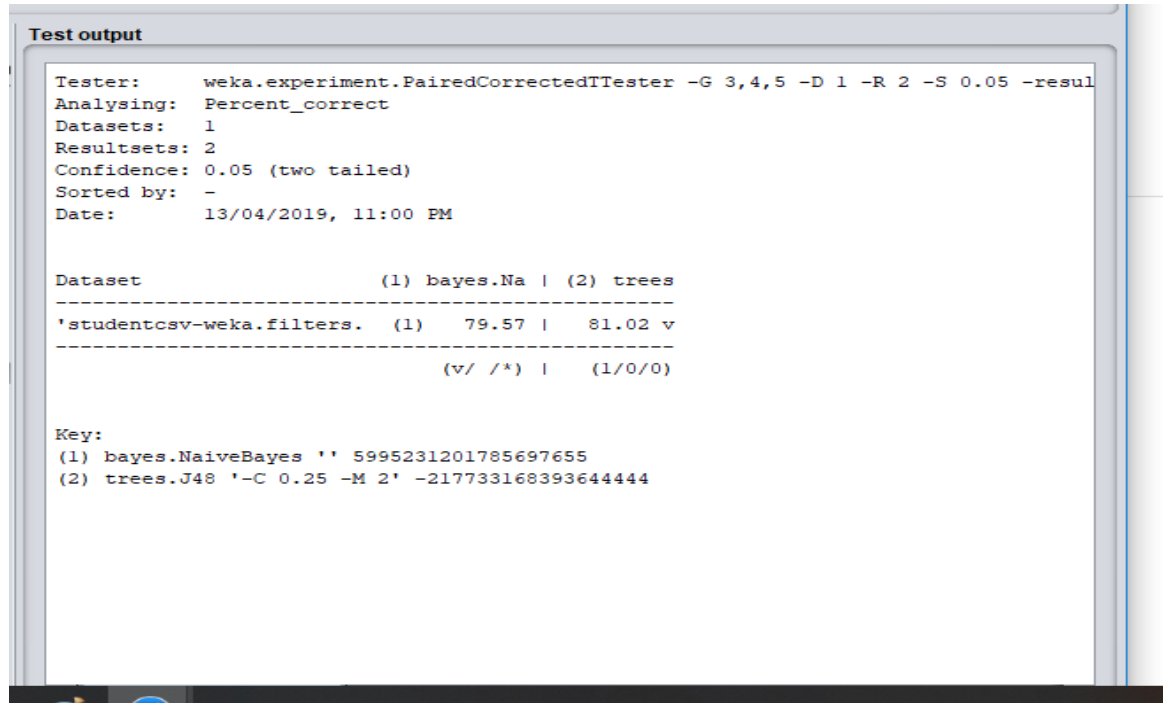

Figure 4. Result of data accuracy from WEKA comparing Naïve Bayes and J48. 
assessment were verified its accuracy and tested using Classification System Algorithm such as Naïve Bays and J48. The screen results are shown in Figure 4.

It shows that the Model used the Decision Tree (J48) has higher accuracy than Naïve Bayes.

\section{Conclusion}

The researcher successfully identifies mechanisms on dynamic data sources for gender and development. The implementation of Decision Tree Algorithm to the computer applications give so much help for the GAD Focal Point system in identifying the solutions to the problems identified from data gathered. They have instant data sources that can help to manage, monitor the GAD projects, and numerous GAD solutions can be identified which is necessary for planning, programming, and policy formulation. Upon operation of this scheme, the SUCs must prepare a better set-up of computer laboratory with fast internet connection and good computer specifications for better system performance.

\section{Acknowledgements}

The authors sincerely appreciate all the insights and expertise shared by the GAD focal persons of the different SUCs, faculty members from Angeles University Foundation, administrators, students and employees of Nueva Ecija University of Science and Technology, staff of Commission on Higher Education R3, Philippine Commission on Women and to our families who always encouraged us in doing and make this study completed.

\section{Conflicts of Interest}

The authors declare no conflicts of interest regarding the publication of this paper.

\section{References}

[1] CMO-No.-01-s.-2015. 24. https://ched.gov.ph/wp-content/uploads/2017/10/CMO-no.-01-s.-2015.pdf https://doi.org/10.1055/s-0035-1558946

[2] Philippine Plan for Gender and Development (PPGD). 5. https://pcw.gov.ph/sites/default/files/documents/resources/ppgd_framework.pdf

[3] Senate and House of Representatives of the Philippines in Congress (2008) Republic Act 9710 an Act Providing for the Magna Carta of Women. 7.

[4] Mananzan, M.J. (2015) Gender Programs to Be Mainstreamed in PH Academe. http://newsinfo.inquirer.net

[5] CMO-No.-01-s.-2015. 25. https://ched.gov.ph/wp-content/uploads/2017/10/CMO-no.-01-s.-2015.pdf

[6] GAD Database. http://www.losbanos.gov.ph/gender-and-development/page/1

[7] Cornwall, A. (2000) Making a Difference? Gender and Participatory Development. Institute of Development Studies.

[8] Eveline, J. and Bacchi, C. (2016) What Are We Mainstreaming When We Main- 
stream Gender. International Feminist Journal of Politics, 7, 496-512. https://doi.org/10.1080/14616740500284417

[9] McNutt, K. and Béland, D. (2016) Implementing an Integrated Governance Strategy: The Quest for Gender Mainstreaming in Canada. American Review of Canadian Studies, 45, 467-485. https://doi.org/10.1080/02722011.2015.1116591

[10] Kaur, G. and Chhabra, A. (2014) Improved J48 Classification Algorithm for the Prediction of Diabetes. International Journal of Computer Applications, 98, 13-17. https://doi.org/10.5120/17314-7433

[11] Song, Y.-Y. and Lu, Y. (2015) Decision Tree Methods: Applications for Classification and Prediction. Shanghai Archives of Psychiatry, 27, 130-139.

[12] Phyu, T.N. (2009) Survey of Classification Techniques in Data Mining. Proceedings of the 2009 International Multi Conference of Engineers and Computer Scientists, 18-20 March 2009, Hong Kong.

[13] Baik, S. and Bala, J. (2004) A Decision Tree Algorithm for Distributed Data Mining: Towards Network Intrusion Detection. In: Laganá, A., Gavrilova, M.L., Kumar, V., Mun, Y., Tan, C.J.K. and Gervasi, O., Eds., Computational Science and Its Applications. ICCSA 2004. Lecture Notes in Computer Science, Springer, Berlin, Heidelberg, 206-212. https://doi.org/10.1007/978-3-540-24768-5_22

[14] Automation-Definitions from Dictionary.com. https://dictionary.reference.com

[15] Understanding the Evolution and Importance of Business Process Automation. https://smartsheet.com

[16] Richey, R. and Klein, J.D. (2015) Developmental Research Methods: Creating Knowledge from Instructional Design and Development Practice. Journal of Computing in Higher Education, 16, 23-38. http://www.researchgate.net/publication https://doi.org/10.1007/BF02961473

[17] Pressman, R. (2010) Software Engineering the Practitioners Approach. McGraw-Hill, New York. 